now published, shows that the institute, which is largely supported by funds from the Department of Agriculture and Fisheries for Scotland and by the Agricultural Research Council (and by industrial concerns as well), is full of life. A scientific and experimental staff of more than a hundred works in seven research departments on topics ranging from the biochemistry of animal and plant tissues to nitrogen metabolism of rumen bacteria and the effects of iron compounds on the virulence of $E$. coli.

Investigations are in progress on the release mechanism of thyrocalcitonin which is the hormone released from the light cells of the thyroid gland when blood calcium levels are higher than normal. According to Dr A. D. Care, glucagon can also stimulate thyrocalcitonin release; thyroid perfusion experiments in vivo have demonstrated that cyclic $3^{\prime} 5^{\prime}$-AMP increases the stimulatory effects of hypercalcaemia and inhibitors of $3^{\prime} 5^{\prime}$-AMP diesterase also have this effect.

The metabolic role of zinc is of special interest. Dr J. Quarteman, who is one of the organizers of the European Symposium on Trace Elements Metabolism which is to take place in Aberdeen in July 1969, has summarized in the report the institute's recent work on zine metabolism.

\section{FISH BIOLOGY}

\section{Trouble in Greenland}

AGAINST a background of international concern about the survival of the Atlantic salmon (Nature, 222, 316; 1969), the Fisheries Society of the British Isles began its spring meeting on April 25 with an account of some of the research in progress on the salmon fishery off the west coast of Greenland. Mr A. Swain (Ministry of Agriculture, London) said that a fishery did not develop in this area until 1961. To start with, all the salmon were taken in inshore waters by local fishermen using gill nets, but in 1965 an offshore fishery using drift nets and involving other countries bogan to operate. It is this development which is causing the most concern-the estimated total catch in 1968 was 1,200 metric tons. Greenland has only one salmon river of any note, and so most of the fish being caught by the offshore fishery must have come from elsewhere. The Canadian stocks are probably being affected most by the developing industry, but tagging has shown that fish from Iceland, England, Scotland, and Ireland are also involved. But nobody seems to know the precise effect of the fishery on home stocks - whether the salmon would have returned to their home waters if they had not been, caught in the high seas. So far, the fishery does not seem to have had a marked effect on British stocks.

Annual visits have been made to Greenland since 1965 , but it has not been easy to collect data. For one thing, only about a third of the fish caught by gill nets were in a fit state to be tagged. In 1968, long-line nets were tried out but even these were not completely successful because the baited hook sometimes stuck in the fish's guts. Modifications are being made for this year's research. Of the 1,326 fish tagged (mostly caught by gill nets) in the three years 1965-67, $\mathrm{Mr}$ Swain reported that thirty-five had been recaptured in local (Greenland) waters and nine in British waters. It will naturally take time to get anything like quantita- tive effects of the Greenland fishery on national stocks, and some authorities fear that by the time the statistics have been collected the fish may be on the verge of extinction.

Mr J. W. Smith (Ministry of Agriculture, Aberdeen) talked about parasites as a source of information on the biology of salmon and hake. Certain fish parasites can give clues to the origin of species and their migratory movements. The hake, Merluccius merluccius, fished off the British Isles seems to have a distinctive parasitic blood fluke which could be used as a bjological tag.

Mr J. M. Hellawell (Freshwater Biological Association) has been studying the effects of coarsc fish on salmonids, particularly salmon parr, in two salmon rivers (Lugg and Llynfi) in the Wye area. Of the thirteen coarse fish in these rivers, chub, dace, roach and grayling are the most common, but contrary to the views of some anglers $\mathrm{Mr}$ Hellawell found that these fish were not seriously competing with the salmonids for food. His conclusions confirm the results of other studies which have indicated that the diets of freshwater fish overlap only slightly. Although no fish has a completely specific diet, each species has particular preferences for certain food. Salmon parr may indeed be subjected to greater competition from the other parr and from trout in the river rather than from the coarse fish.

\section{UNIVERSITY ARCHITECTURE}

\section{Chemical Engineering at Bradford}

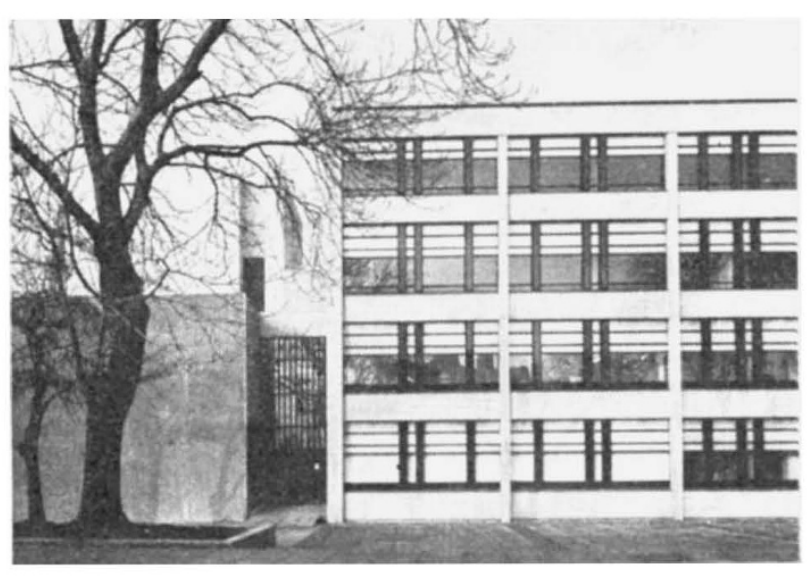

The chemical engineering building at the University of Bradford was opened on April 26. Designed by Building Design Partnership in association with the university's resident architect, it is the first completed section of the continuous linear academic building included in the Development Plan. Partitions, ceilings, services and their distribution systems in the new building can be moved and the plan rearranged.

\section{PLANNING}

\section{London's Sprawl}

\section{from our Planning Correspondent}

ANOTHER call for more decentralization of office cmployment in central London is made in a new broadsheet from PEP (Political and Economic Planning) (London's New Towns, PEP Broadsheet 510 , 10s). The author, Ray Thomas, an economist on 
three years' leave from the planning department of the Greater London Council, would like to see half a million jobs moved out of central London in the next decade, and he suggests that employers could be given more encouragement to move out by enlarging the scope of the Location of Offices Bureau, by tightening up the Office Development Permit System and by special taxes and incentives. With London's resident labour force declining steadily, the imbalance between the levels of employment and population will increase dramatically unless large scale decentralization takes place. There could in fact be an employment surplus of 700,000 by 1981 , the broadsheet says. If this happened, there would need to be heavy investment in improving the railway systems and road networks. The idea of preserving a green belt around London would seem utopian and London would sprawl as it never sprawled before.

The crux of the problem is the concentration of $1,300,000$ jobs in the centre. This concentration is inherited from the days of barges and ships, carriages, stage coaches and steam trains, servants and messenger boys, quill pens and inkstands. The usual means of communication involved a visit or a letter in the penny post. These means of communication have been replaced by delivery vans, containers and articulated

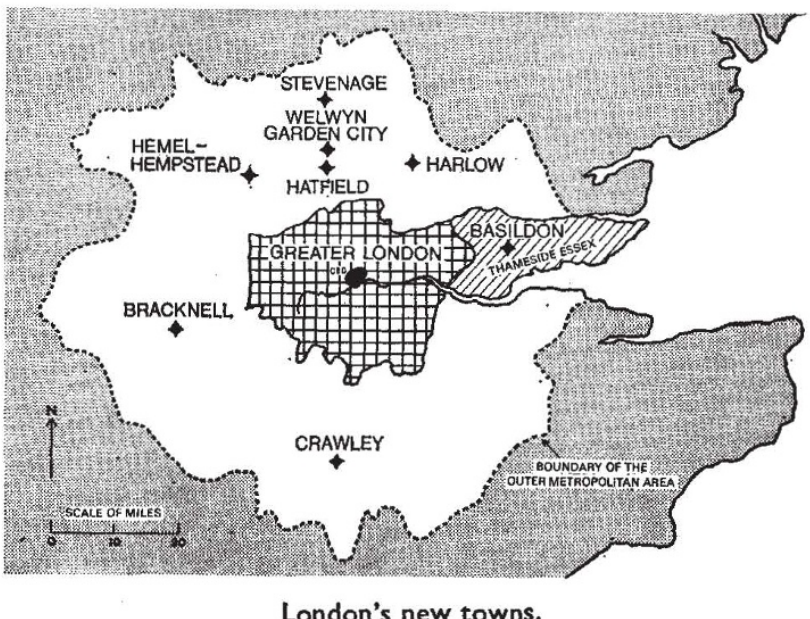

lorries, motor cars, jet planes, subscriber trunk dialling, computers and xerox machines. Unfortunately, the central business district of London has stagnated during this revolution, the broadsheet says, and little has been done to improve people's journeys to work. The situation could be eased, however, if the lessons from London's new towns were taken to heart. These towns (Basildon, Bracknell, Crawley, Harlow, Hemel Hempstead, Stevenage and Welwyn Garden City), the product of the policy proposed in Abercrombie's Greater London Plan in 1944, have shown the way to a solution of London's journey to work and housing problems. Mr Thomas shows that they have acted as countermagnets to London's growth because they have provided nearly 200,000 jobs in the Outer Metropolitan Area. Contrary to many reports, he has found the new towns self-contained and balanced communities for living and working.

As a case study, the broadsheet takes the impact of the development of Basildon on its hinterland of Thameside Essex. The new town has helped to remedy a massive deficit in employment in this area by gaining 30,000 jobs, but only 20,000 residents in employment. One in seven of the resident employed population in Basildon travels to London to work (a higher proportion than any of the other new towns), but the proportion travelling from Basildon is much smaller than from any other parts of Thameside Essex. More than one in five commute to London from the Southend area. There is a deficit of 40,000 jobs there, and unemployment rates justify development area status. Southend, together with its neighbours, Benfleet, Canvey Island, Rayleigh and Rochford, probably has the largest employment deficit and the longest journey to work in the country. The broadsheet says that if London's third airport were sited at Foulness-a few miles to the east-the situation in the area would be changed. rapidly as it was in Basildon, and there would probably be a substantial drop in the numbers commuting to London.

\section{POWER \\ New Method of Combustion}

THe National Coal Board is determined to convince both the Central Electricity Generating Board and the British Government that its new efficient method of burning coal known as fluidized combustion has a rightful place in the power stations of the next decade. Mr L. Grainger, member for research at the coal board, revealed the advanced stage of research on this technique at the NCB research station at Stoke Orchard, Gloucestershire, last week. He said that if all of several hurdles were successfully jumped in the months ahead, there could be a 660 Megawatt power station using fluidized combustion in operation by 1976 .

The benefits of using fluidized combustion instead of conventional plants for producing steam are quite substantial, and the CEGB may well be regretting its decision to opt out of the fluidized combustion programme a few years ago. The special feature of the process is that, by blowing air through finely ground coal, it is possible to increase the rate of transfer of heat in the furnace by a factor of three. Furthermore, the operating temperature can be lowered from the normal $1,200^{\circ}-1,600^{\circ} \mathrm{C}$ to the much less corrosive $800^{\circ} \mathrm{C}$, and the size of the combustion chamber itself can be considerably reduced. The coal fragments can also be relatively coarse. It is the fluidizing effect of the air on the coal that allows these considerable benefits to be achieved.

The saving of capital costs by building a fluidized combustion plant rather than a conventional power station is estimated at about 10 per cent, with a reduction of running costs of between 5 and 10 per cent. Why, then, is the implementation of fluidized combustion in power stations in question?

The answer is tied up with the future of the coal industry. The CEGB estimates that nuclear power will increase its share of electricity production in Britain from the present 10 per cent to about 25 per cent by 1975. At the same time, the coal industry reckons that after 1975, about two-thirds of the coal produced in Britain will be for power generation. There is clearly a delicate balancing act ahead for the NCB. Nuclear power stations cost considerably more to build than coal power stations, of course, but Mr Grainger con- 